\title{
QSPR Modeling using Catalan Solvent and Solute Parameters
}

\author{
Abolghasem Jouyban, *,a Mohammad A. A. Fakhree, ${ }^{b}$ Ali Shayanfar ${ }^{c}$ and \\ Taravat Ghafourian ${ }^{d}$
}

\author{
${ }^{a}$ Drug Applied Research Center, Department of Pharmaceutical and Food Control, \\ Faculty of Pharmacy, Tabriz University of Medical Sciences, Tabriz 51664, Iran
}

\author{
${ }^{b}$ Kimia Research Institute, Tabriz, Iran \\ ${ }^{c}$ Liver and Gastrointestinal Diseases Research Center, Tabriz University of \\ Medical Sciences, Tabriz, Iran \\ ${ }^{d}$ Medway School of Pharmacy, Universities of Kent and Greenwich, \\ Kent ME4 4TB, United Kingdom
}

\begin{abstract}
A área de correlação quantitativa entre estrutura e propriedade (QSPR) pode beneficiar-se de descritores moleculares que representam interações intermoleculares. Catalan desenvolveu um método de escalas solvatocrômicas para solventes que pode ser explorado para esta finalidade. Neste trabalho, escalas de solvente de Catalan foram usadas como descritores moleculares para o desenvolvimento de modelos QSPR, e para o cálculo de novos descritores de soluto para uso posterior em QSPR. As escalas Catalan para o solvente e os descritores de soluto derivados foram recentemente comparados com o método de descritores de Abraham, em termos da qualidade do QSPR desenvolvido. Os parâmetros Catalan para solventes, que mostraram uma correlação modesta com os correspondentes descritores de Abraham, mostraram-se bem sucedidos para modelar temperatura de fusão, temperatura de ebulição, ponto de ignição, índice de refração, tensão superficial, densidade e parâmetro de solubilidade dos solventes, com médias geométricas dos desvios relativos (GMRD) de 7,1, 6,6, 4,9, 3,8, 9,1, 6,0 e 4,2\%, respectivamente. Os descritores do soluto foram obtidos a partir das equações de regressão entre a solubilidade de um soluto em diferentes solventes com um GMRD total de 30,0\%. Os descritores de soluto obtidos desta maneira superam o modelo de solvatação geral de Abraham no cálculo de solubilidade em meio aquoso de 27 solutos de várias famílias químicas. Os descritores Catalan podem ser considerados como um recurso valioso para modelagem QSPR.
\end{abstract}

The field of quantitative structure-property relationship (QSPR) can greatly benefit from molecular descriptors that particularly represent the intermolecular interactions. Catalan has developed a set of solvatochromic scales for solvents, which could be exploited for this purpose. In this work, Catalan solvent scales were explored as molecular descriptors for the development of QSPR models, and for the calculation of new solute descriptors for further use in QSPR. Catalan solvent scales and the newly derived solute descriptors were compared with the commonly used set of Abraham descriptors in terms of the quality of the developed QSPRs. Catalan solvent parameters, which showed modest correlation with the corresponding Abraham descriptors, proved to be successful in modeling melting point, boiling point, flash point, refractive index, surface tension, density, and solubility parameter of the solvents with geometric mean relative deviations (GMRD) of 7.1, 6.6, 4.9, 3.8, 9.1, 6.0, and 4.2\%, respectively. The solute descriptors were obtained from regression equations between a solute's solubility in different solvents with an overall GMRD of $30.0 \%$. The solute descriptors obtained in this way outperformed Abraham general solvation model in the calculation of aqueous solubility for 27 solutes of broad chemical ranges. It was concluded that Catalan descriptors can be regarded as a valuable resource for QSPR modeling.

Keywords: Catalan, solvatochromic, solubility, modeling, QSPR

*e-mail: ajouyban@hotmail.com 


\section{Introduction}

Solubility of a compound in different solvents such as water and 1-octanol can be used in quantitative structureproperty relationships (QSPRs) as a measure of its property in phases similar to those solvents. ${ }^{1}$ Solubility not only can be used directly as a molecular descriptor, but also other parameters can be derived from solubility and employed as molecular descriptors of QSPR. Examples of such solubility-related parameters include thermodynamic solubility parameter of Hildebrand, ${ }^{1}$ and solvatochromic parameters. ${ }^{2-8}$ A set of solvatochromic parameters was originally derived from spectroscopic methods of investigating the intermolecular interactions by Kamlet, Taft, and Abraham in 1970-1980..$^{2-5}$ The parameters included solvent polarity/polarizability scale, solvent basicity scale, and solvent acidity scale, which were then used in QSPR models to estimate properties and activities of solvents or solutes in the solutions. ${ }^{2-5}$ The parameter set was later extended to the corresponding solute descriptors of hydrogen-bonding acidity (A) and basicity (B) scales, and polarity/polarizability (S) scale. ${ }^{9}{ }^{10}$ In addition to these parameters, the general solvation equation proposed by Abraham and co-workers ${ }^{9,10}$ (equation 1) also includes excess molar refraction (E) and the one percent of McGowan molar volume (V).

$\mathrm{PCP}=\mathrm{c}+\mathrm{eE}+\mathrm{sS}+\mathrm{aA}+\mathrm{bB}+\mathrm{vV}$

In equation 1, PCP is a property under study; c, e, s, a, $\mathrm{b}$, and $\mathrm{v}$ are the coefficients of the model determined by multiple linear regression analysis. Abraham parameters have found many applications in chemistry and pharmacyrelated fields, for example estimations of solubility, ${ }^{6}$ partitioning, ${ }^{11}$ chromatographic retention parameters, ${ }^{12}$ toxicity, ${ }^{13,14}$ and intestinal absorption. ${ }^{15}$ Due to the experimental nature of $\mathrm{A}, \mathrm{B}$, and $\mathrm{S}$ parameters, several methods have been suggested for their determination from the experimental data. ${ }^{16-18}$ Moreover, a method has been suggested for the back calculation of solute Abraham parameters recently, which employs the calculated $\mathrm{E}$ and $\mathrm{V}$ parameters along with the experimental solubility of solutes in several organic solvents and the previously determined solvent coefficients of equation 1 (c, e, s, a, b, and v) for partitioning in a large number of water/solvent systems, followed by fitting the appropriate values of S, A and B. ${ }^{19}$

Catalan has expanded another set of solvatochromic parameters for a generalized treatment of the effects of solvents. ${ }^{7}$ Catalan parameters consist of solvent polarity/ polarizability scale (SPP), solvent basicity scale (SB defined as cb in this work), and solvent acidity scale (SA defined as ca in this work), ${ }^{8,20-23}$ which recently SPP parameter split into two separate scales: solvent dipolarity (SdP defined as cd in this work) and solvent polarizability (SP defined as cp in this work). ${ }^{7}$ The approach for measuring these parameters is similar to those of Kamlet and Taft, ${ }^{2,3}$ where a probe with specific interactions with solvent has been used and variances in spectroscopy data have been recorded and applied for the definition of the solvent scales. ${ }^{2-4,8,20-23}$ In formulating the independent solvent scales, the choice of an appropriate probe for the experimental determination of the scales is the major challenge. The selected probe should measure the effect of a single solvent property, for example, hydrogen-bonding basicity, without the interference of any other solvent effects. Solvatochromic scales of Catalan have employed different probes to those used for the development of Kamlet and Taft's scales.

This investigation explored the suitability of Catalan solvent parameters for use in QSPR field and the possibility of drawing new solute parameters from original Catalan scale. Therefore, Abraham and Catalan solvent parameters were first compared by investigating the relationships between the two sets of parameters. Secondly, Catalan solvent parameters were used for the development of QSPR models for several solvent properties and the validity of the resulting QSPRs was investigated. The solvent properties included melting point, boiling point, flash point, refractive index, surface tension, viscosity, density, and solubility parameter. In the next step, Catalan solute parameters were derived based on the correlations between a solute solubility in several nonaqueous solvents and Catalan solvent scales for those solvents. Finally, the applicability of these newly defined solute parameters for the prediction of the molar aqueous solubility of some compounds was investigated and the resulting QSPR was compared with the QSPR models developed using Abraham parameters.

\section{Experimental}

\section{Materials and methods}

Solvent properties, Abraham and Catalan parameters were collected from the literature, as detailed below, and multiple linear regression analysis was used to investigate the relationships and to develop the QSPR models using Catalan and Abraham parameters (for more details see Table S1 of electronic supplementary information).

Inter-relationship between Catalan and Abraham solvent parameters: Catalan solvent parameters were obtained from a recent publication. ${ }^{7}$ Abraham solvent parameters were collected from the literature. ${ }^{24-42}$ Regression 
analyses were performed to find the relationships between the corresponding polarity/polarizability, hydrogenbonding basicity, and hydrogen-bonding acidity scales of Abraham and Catalan.

Development of QSPR models using Catalan solvent parameters: Melting point, boiling point, flash point, refractive index, surface tension, viscosity, density, and solubility parameter of 54 common solvents with known Catalan solvent parameters were obtained from the literature. ${ }^{43}$ Catalan descriptors were used to develop regression models for the above-mentioned physicochemical properties.

Determination of Catalan solute descriptors: Mole fraction solubility of a large set of compounds in several nonaqueous solvents was obtained from Handbook of Solubility Data for Pharmaceuticals. ${ }^{44}$ The inclusion criteria for the collected nonaqueous solubility data in this study were:

(i) Only the solubility values measured at room temperature $\left(25 \pm 1^{\circ} \mathrm{C}\right)$ were included.

(ii) Only solubility values reported in mole fraction, mole per liter or those that were convertible to one of these units were used.

(iii) For inclusion in the analysis, solubility of a solute had to be available in a minimum of eleven nonaqueous solvents.

For each solute, the logarithm of solubility in different solvents was regressed against Catalan parameters of the solvents and the regression equations were collected as below.

$\log \mathrm{X}=\mathrm{i}_{\text {Solute }}+\mathrm{CP} \mathrm{cp}+\mathrm{CD} \mathrm{cd}+\mathrm{CAcb}+\mathrm{CB}$ ca

In equation $2, \log \mathrm{X}$ is the solubility of a solute in different solvents in mole fraction unit, cp, cd, cb, and ca are Catalan polarizability, dipolarity, hydrogen-bonding basicity, and acidity scales for the solvents, $\mathrm{i}_{\text {Solute }}$ is the intercept, CP, DP, CA, and CB are coefficients of the regression equation. The coefficients of the regression equations for each solute were recorded to be used as the solute polarizability, dipolarity, hydrogen-bonding acidity, and basicity scales.

\section{Application of Catalan and Abraham solute parameters in QSPR model development for aqueous solubility}

Solute descriptors were calculated using Catalan solvent parameters (as explained above) for 27 solutes for which aqueous solubility and Abraham solute descriptors ${ }^{24-42}$ were available through recent publications. For these solutes, the new solute parameters were compared with Abraham solute descriptors in terms of: the accuracy of the original equation used for the estimation of solute parameters; and the accuracy of the models developed for the estimation of aqueous solubility of 27 solutes. For this purpose, the Catalan model was:

$\log S_{w}=i_{W}+\alpha_{P} C P+\alpha_{D} C D+\alpha_{A} C B+\alpha_{B} C A+i_{\text {solute }}$

By rearranging the equation as below, it allows one to perform a regression analysis:

$\log \mathrm{S}_{\mathrm{w}}-\mathrm{i}_{\text {Solute }}=\mathrm{i}_{\mathrm{W}}+\alpha_{\mathrm{P}} \mathrm{CP}+\alpha_{\mathrm{D}} \mathrm{CD}+\alpha_{\mathrm{A}} \mathrm{CB}+\alpha_{\mathrm{B}} \mathrm{CA}$

where $i_{w}$ is the intercept of regression of aqueous solubility data against Catalan solute parameters computed from equation $2 ; \alpha_{\mathrm{p}}, \alpha_{\mathrm{D}}, \alpha_{\mathrm{B}}$, and $\alpha_{\mathrm{A}}$ are the regression coefficients, which correspond to the calculated Catalan solvent scales of polarizability, dipolarity, basicity, and acidity for water.

The comparable Abraham solvation mode ${ }^{27}$ reported in the literature for aqueous solubility is:

$\log \mathrm{S}_{\mathrm{w}}=0.395-0.955 \mathrm{E}+0.320 \mathrm{~S}+1.155 \mathrm{~A}+3.255 \mathrm{~B}-$ $0.785 \mathrm{AB}-3.330 \mathrm{~V}$

Equations 4 and 5 were compared in terms of the accuracy of the calculation of aqueous solubility. In the analyses of this study, relative deviation (RD), mean relative deviation (MRD), geometric MRD (GMRD) and absolute error (AE) were used as error criteria and defined as:

$$
\begin{aligned}
& R D=\frac{100 \times\left|P C P_{E x p}-P C P_{C a l}\right|}{P C P_{E x p}} \quad M R D=\frac{100}{n} \sum \frac{\left|P C P_{E x p}-P C P_{C a l}\right|}{P C P_{E x p}} \\
& G M R D=10^{\wedge} \frac{100}{n} \sum \log \left(\frac{\left|P C P_{E x p}-P C P_{C a l}\right|}{P C P_{E x p}}\right) \quad A E=\left|\log P C P_{E x p}-\log P C P_{C a l}\right|
\end{aligned}
$$

where $\mathrm{n}$ is the number of data points in each analysis, $\mathrm{PCP}_{\mathrm{Exp}}$ and $\mathrm{PCP}_{\mathrm{Cal}}$ are the experimental and calculated PCP.

\section{Results and Discussion}

Table S2 of electronic supplementary information (SI) tabulates 41 solvents for which Catalan solvent parameters and Abraham solvent parameters were available from the literature. The correlation parameters between Catalan and Abraham solvent parameters for 41 solvents showed modest correlation coefficients (Table 1).

Based on definition of the Catalan, the $\mathrm{CP}, \mathrm{CD}, \mathrm{CB}$, and $\mathrm{CA}$ are polarizability, dipolarity, basicity, and acidity of the solvents, respectively. ${ }^{718-23}$ The Abraham solvent parameters 
Table 1. Correlation of Abraham solvent parameters vs. Catalan solvent parameters for 41 solvents

\begin{tabular}{lcccc}
\hline & $\mathrm{r}^{2}$ & $\mathrm{SE}$ & $\mathrm{F}$ & $\mathrm{p}$ value \\
\hline s-CP & 0.093 & 0.605 & 3.992 & $<0.05$ \\
s-CD & 0.526 & 0.437 & 43.212 & $<0.0005$ \\
a-CB & 0.872 & 0.620 & 266.354 & $<0.0005$ \\
b-CA & 0.704 & 0.363 & 92.768 & $<0.0005$ \\
\hline
\end{tabular}

$\mathrm{s}$, $\mathrm{a}$, and $\mathrm{b}$ are the interaction terms of the solvents with $\mathrm{S}$, $\mathrm{A}$, and B of the solute, respectively. As the S, A, and B are indicators of the solute's polarity, acidity, and basicity, hence the $\mathrm{s}, \mathrm{a}$, and $\mathrm{b}$ are indicators of solvent polarity, basicity, and acidity, respectively ${ }^{45}$ All investigated correlations reported in Table 1 were statistically significant $(\mathrm{p}<0.05)$.

Melting point, boiling point, flash point, refractive index, surface tension, viscosity, density, and solubility parameter of 54 common solvents with the known Catalan solvent parameters are listed in Table S3 in SI. The QSPRs developed using Catalan solvent scales for these physicochemical properties are reported in Table 2. Careful examinations of these results reveal very good models fit for melting point, boiling point, flash point, refractive index, surface tension, density, and solubility parameter of the solvents. However, viscosity did not fit well into the Catalan model. Figure 1 shows correlation between experimental and calculated solubility parameters for the studied solvents.

Table 3 presents, for each solute, the equations derived for the solubility in several nonaqueous solvents. Reported data in Table 3 are the coefficients of multiple linear regression $\left(\mathrm{r}^{2}\right)$ equations between the compounds' solubility in nonaqueous solvents and Catalan solvent parameters (data fitted into equation 2) for 37 different compounds in which the solutes solubility was expressed as mole fractions. Included in Table 3 are also the coefficients of determinations of the regression equations, number of solvents used for each solute, AE and MRD values.

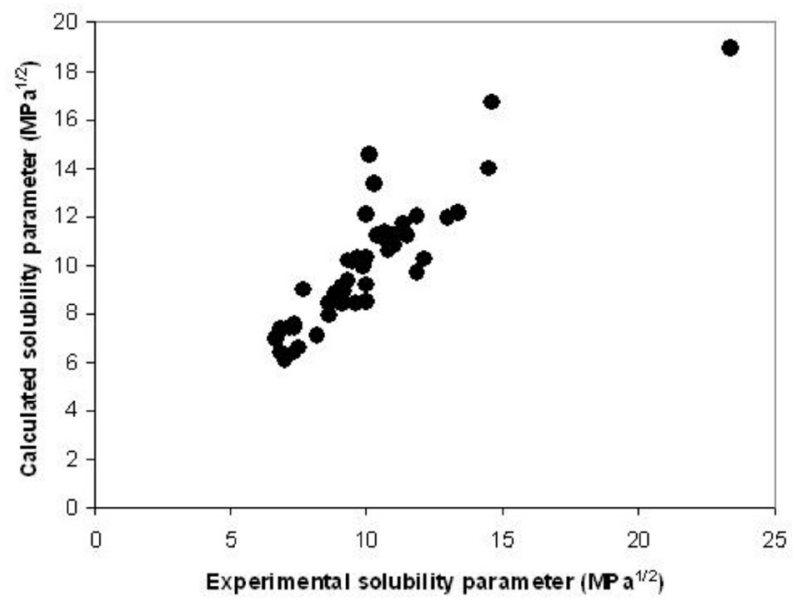

Figure 1. Correlation between experimental and calculated solubility parameters using Catalan solvent scales for the studied solvents.

We are proposing that the coefficients of these multiple regression equations are associated with the characteristics of the solutes and can be used as the corresponding solute parameters. It can be seen in Table 3 that the MRD values of the equations vary between $2.6 \%$ for methandienone solubility in 11 solvents and $776.9 \%$ for niflumic acid solubility in 23 solvents and the GMRD is $30.0 \%$. Despite the low correlation coefficients of the models for some solutes such as niflumic acid, piroxicam and ibuprofen, the equations were statistically significant with $p$-values below 0.05 for the equation and p-values for the significant descriptors $<0.3$. One explanation for the poor correlations observed for some solutes could be the dominant effect of crystal packing energy on the solubility of such solvents. These effects cannot be explained solely by simple parameters such as those used here, and are assumed to be related to the specific three-dimensional arrangements of molecules within the crystals. A similar pattern was observed for AE.

In assessing the resulted Catalan solute parameters, one must consider that: $(i)$ the resulted acidic and basic scales

Table 2. Coefficients of PCP $=\alpha_{1} \mathrm{cp}+\alpha_{2} \mathrm{~cd}+\alpha_{3} \mathrm{ca}+\alpha_{4} \mathrm{cb}$ (Catalan model) for calculating some solvents' PCP

\begin{tabular}{|c|c|c|c|c|c|c|c|}
\hline PCP & $\alpha_{1}$ & $\alpha_{2}$ & $\alpha_{3}$ & $\alpha_{4}$ & $\mathrm{n}$ & $r^{2}$ & $\operatorname{GMRD}(\%)$ \\
\hline Melting point $(\mathrm{K})$ & 295.312 & 21.756 & 41.954 & -37.478 & 53 & 0.972 & 7.1 \\
\hline Boiling point $(\mathrm{K})$ & 494.143 & $\mathrm{NS}^{\mathrm{a}}$ & 44.328 & 62.548 & 54 & 0.985 & 6.6 \\
\hline Flash point $(\mathrm{K})$ & 368.468 & 23.549 & 74.712 & 28.389 & 49 & 0.987 & 4.9 \\
\hline Refractive index & 1.964 & -0.182 & 0.215 & 0.118 & 54 & 0.995 & 3.8 \\
\hline Surface tension $\left(\mathrm{dyn} \mathrm{cm}^{-1}\right)$ & 34.751 & 12.188 & 21.750 & -12.534 & 53 & 0.938 & 9.1 \\
\hline Viscosity (cP) & $\mathrm{NS}^{\mathrm{a}}$ & $\mathrm{NS}^{\mathrm{a}}$ & 3.300 & 11.230 & 53 & 0.238 & 89.2 \\
\hline Density $\left(\mathrm{g} \mathrm{cm}^{-3}\right)$ & 1.273 & 0.196 & $\mathrm{NS}^{\mathrm{a}}$ & -0.230 & 54 & 0.977 & 6.0 \\
\hline Solubility parameter $\left(\mathrm{MPa}^{1 / 2}\right)$ & 10.350 & 2.725 & 8.665 & $\mathrm{NS}^{\mathrm{a}}$ & 48 & 0.984 & 4.2 \\
\hline
\end{tabular}

${ }^{a}$ NS: Not significant. 
are based on the behavior of solute in nonaqueous solvents. It means that an acid in water could act in a different way, i.e. as a neutral or basic compound, in the organic solvents; (ii) the coefficients of the Catalan solute parameters might indicate the effect of acidic or even basic functional groups of the compound on its solubility in organic solvents, therefore the numerical values of the coefficient could be a positive or negative sign.
In order to examine the suitability of the new Catalan solute parameters for QSPR modeling, the parameters were used for the estimation of aqueous solubility. Moreover, the model was compared with the model developed using Abraham solute parameters obtained using a similar back-calculation procedure, ${ }^{24-42}$ and also Abraham aqueous solubility model reported in the literature. ${ }^{27}$ Listed in Table 4 are molar aqueous solubility

Table 3. Catalan solute parameters for the studied solutes with mole fraction solubilities, coefficients of determination, mean relative deviation (MRD) and absolute error (AE) values

\begin{tabular}{|c|c|c|c|c|c|c|c|c|c|c|c|}
\hline No. & Solute & CAS & $\mathrm{n}$ & $\mathrm{i}_{\text {Solute }}$ & $\mathrm{CP}$ & $\mathrm{CD}$ & $\mathrm{CB}$ & $\mathrm{CA}$ & $\mathrm{r}^{2}$ & MRD & $\mathrm{AE}$ \\
\hline 1 & 2-Hydroxybenzoic acid & $69-72-7$ & 33 & -4.065 & 1.650 & 0.683 & $\mathrm{NS}^{\mathrm{a}}$ & 2.486 & 0.741 & 102.8 & 0.37 \\
\hline 2 & 4-Aminobenzoic acid & $150-13-0$ & 28 & -4.545 & $\mathrm{NS}^{\mathrm{a}}$ & 2.549 & $\mathrm{NS}^{\mathrm{a}}$ & 1.864 & 0.660 & 259.5 & 0.49 \\
\hline 3 & 4-Hydroxybenzoic acid & $99-96-7$ & 26 & -4.778 & $N^{a}$ & 1.932 & $\mathrm{NS}^{\mathrm{a}}$ & 3.551 & 0.783 & 160.0 & 0.48 \\
\hline 4 & Acetylsalicylic acid & $50-78-2$ & 28 & $\mathrm{NS}^{\mathrm{a}}$ & -3.196 & 0.872 & $\mathrm{NS}^{\mathrm{a}}$ & 0.342 & 0.934 & 75.6 & 0.26 \\
\hline 5 & Anthracene & $120-12-7$ & 30 & -5.953 & 4.797 & $\mathrm{NS}^{\mathrm{a}}$ & -3.025 & 0.623 & 0.842 & 32.0 & 0.13 \\
\hline 6 & Benzil & $134-81-6$ & 16 & -6.351 & 6.535 & 1.080 & -3.557 & 0.540 & 0.714 & 32.4 & 0.13 \\
\hline 7 & Benzoic acid & $65-85-0$ & 37 & -2.992 & 1.747 & 0.625 & $\mathrm{NS}^{\mathrm{a}}$ & 0.935 & 0.750 & 55.8 & 0.21 \\
\hline 8 & Betulin & $473-98-3$ & 11 & -8.031 & 5.681 & 1.267 & -0.893 & 1.012 & 0.750 & 46.8 & 0.19 \\
\hline 9 & Diclofenac & $15307-86-5$ & 21 & -3.532 & $\mathrm{NS}^{\mathrm{a}}$ & 1.594 & -1.452 & 1.563 & 0.537 & 140.8 & 0.46 \\
\hline 10 & Diflunisal & $22494-42-4$ & 11 & -8.609 & 5.757 & 1.863 & 0.776 & 2.124 & 0.999 & 7.1 & 0.03 \\
\hline 11 & Flubiprofen & $5104-49-4$ & 18 & -9.135 & 9.372 & 1.882 & -0.514 & 0.826 & 0.937 & 40.8 & 0.17 \\
\hline 12 & Haloperidol & $52-86-8$ & 15 & -3.375 & 2.040 & $\mathrm{NS}^{\mathrm{a}}$ & -1.056 & $\mathrm{NS}^{\mathrm{a}}$ & 0.362 & 86.9 & 0.33 \\
\hline 13 & Ibuprofen & $15687-27-1$ & 26 & 2.559 & -5.117 & $\mathrm{NS}^{\mathrm{a}}$ & $\mathrm{NS}^{\mathrm{a}}$ & $\mathrm{NS}^{\mathrm{a}}$ & 0.345 & 169.5 & 0.36 \\
\hline 14 & Ketoprofen & $22071-15-4$ & 14 & $\mathrm{NS}^{\mathrm{a}}$ & -2.070 & 0.346 & -1.297 & 0.624 & 0.999 & 5.5 & 0.02 \\
\hline 15 & Lactose & $63-42-3$ & 16 & -13.696 & 9.143 & 2.065 & 2.080 & 1.946 & 0.802 & 210.5 & 0.51 \\
\hline 16 & Mannitol & $69-65-8$ & 11 & -9.063 & 5.761 & 1.727 & 0.895 & $\mathrm{NS}^{\mathrm{a}}$ & 0.952 & 31.5 & 0.13 \\
\hline 17 & Mestanolone & $521-11-9$ & 13 & -7.289 & 5.567 & -1.801 & 6.591 & 0.417 & 0.997 & 7.3 & 0.03 \\
\hline 18 & Methandienone & $72-63-9$ & 11 & -6.111 & 4.010 & -0.697 & 8.369 & -0.163 & 0.999 & 2.6 & 0.01 \\
\hline 19 & Methyl $p$-hydroxybenzoate & $99-76-3$ & 32 & -2.406 & -2.680 & 2.663 & -0.601 & 2.598 & 0.871 & 153.6 & 0.30 \\
\hline 20 & Methyltestosterone & $58-18-4$ & 13 & -6.112 & 4.049 & -1.148 & 7.487 & 0.218 & 0.999 & 3.6 & 0.02 \\
\hline 21 & Nandrolone & $434-22-0$ & 11 & -6.131 & 4.192 & 0.306 & 9.483 & -1.072 & 0.999 & 7.3 & 0.03 \\
\hline 22 & Naproxen & 22204-53-1 & 36 & -2.815 & $\mathrm{NS}^{\mathrm{a}}$ & 1.529 & -1.132 & 0.513 & 0.436 & 105.5 & 0.32 \\
\hline 23 & Niflumic acid & 4394-00-7 & 23 & -3.375 & $\mathrm{NS}^{\mathrm{a}}$ & $\mathrm{NS}^{\mathrm{a}}$ & $\mathrm{NS}^{\mathrm{a}}$ & 2.225 & 0.223 & 776.9 & 0.76 \\
\hline 24 & Paracetamol & $103-90-2$ & 15 & -6.411 & 1.928 & 2.635 & 0.773 & 2.399 & 0.957 & 61.8 & 0.26 \\
\hline 25 & Phenacetin & $62-44-2$ & 11 & -9.073 & 7.148 & 2.798 & -0.728 & 1.369 & 0.941 & 33.5 & 0.15 \\
\hline 26 & Phenothiazine & $92-84-2$ & 30 & -4.438 & 2.120 & 0.739 & -1.546 & 1.295 & 0.632 & 76.0 & 0.25 \\
\hline 27 & Pimozide & $2062-78-4$ & 14 & -8.130 & 5.538 & 1.175 & -2.020 & 2.051 & 0.679 & 88.6 & 0.27 \\
\hline 28 & Piroxicam & $36322-90-4$ & 22 & -4.156 & $\mathrm{NS}^{\mathrm{a}}$ & 1.890 & -1.503 & $\mathrm{NS}^{\mathrm{a}}$ & 0.291 & 307.9 & 0.70 \\
\hline 29 & Pyrene & $129-00-0$ & 19 & -5.938 & 6.099 & -0.393 & -1.482 & 0.409 & 0.895 & 27.4 & 0.11 \\
\hline 30 & Saccharose & $57-50-1$ & 12 & -16.613 & 9.138 & 3.979 & $\mathrm{NS}^{\mathrm{a}}$ & 1.566 & 0.935 & 62.7 & 0.24 \\
\hline 31 & Salicylamide & $65-45-2$ & 24 & -6.272 & 7.076 & 1.240 & $\mathrm{NS}^{\mathrm{a}}$ & -0.901 & 0.515 & 51.2 & 0.17 \\
\hline 32 & Sulfadiazine & $68-35-9$ & 21 & -11.498 & 6.353 & 4.467 & -2.710 & 1.253 & 0.806 & 122.3 & 0.43 \\
\hline 33 & Sulfamethoxypyridazine & $80-35-3$ & 26 & -9.160 & 5.315 & 3.606 & -1.766 & 0.958 & 0.808 & 78.2 & 0.31 \\
\hline 34 & Temazepam & $846-50-4$ & 25 & -6.246 & 5.046 & 1.298 & -2.086 & 0.473 & 0.796 & 57.3 & 0.23 \\
\hline 35 & Testosterone & $58-22-0$ & 11 & -7.430 & 5.667 & -1.507 & 8.968 & 0.212 & 0.999 & 4.0 & 0.02 \\
\hline 36 & Testosterone propionate & $57-85-2$ & 21 & -5.290 & 5.184 & 1.772 & $\mathrm{NS}^{\mathrm{a}}$ & -2.364 & 0.909 & 34.9 & 0.16 \\
\hline 37 & Xanthene & $92-83-1$ & 29 & -4.231 & 4.354 & -0.167 & -1.163 & $\mathrm{NS}^{\mathrm{a}}$ & 0.828 & 25.7 & 0.11 \\
\hline
\end{tabular}

aNS: Not significant. 
and Abraham solute parameters from the literature, and Catalan solute parameters calculated in this study for 27 solutes.

It should be noted that when a model was trained using molar solubilities, it provides more accurate predictions in molar solubilities rather than other solubility expressions. Multiple linear regression analysis against Abraham descriptors and Catalan solute coefficients resulted in equations:

$$
\log \mathrm{S}_{\mathrm{w}}=0.395-0.551 \mathrm{E}+0.528 \mathrm{~S}-0.145 \mathrm{~A}+5.41 \mathrm{~B}-
$$$$
4.790 \mathrm{~V} \quad \mathrm{r}^{2}=0.939
$$

$$
\log \mathrm{S}_{\mathrm{w}}=-3.395+\mathrm{i}_{\text {Solute }}+0.503 \mathrm{CP}+1.726 \mathrm{CD}+0.061 \mathrm{CA}+
$$$$
0.847 \mathrm{CB} \quad \mathrm{r}^{2}=0.969
$$

The coefficients in equation 8 might be related to the effects of the solvent used (in this case water). Catalan solvent parameters for water are $\mathrm{cp}=0.681, \mathrm{~cd}=0.997$, $\mathrm{cb}=0.025$, and $\mathrm{ca}=1.062$, which show a similar trend in comparison with the coefficients of equation 8 . This could indicate the validity and reliability of the suggested method for the calculation of Catalan solute parameters. Also it has been shown that aqueous solubility has indirect correlation with the molecular volume of the compounds. ${ }^{46}$ Based on this fact, the following equation was proposed:

$\log \mathrm{S}_{\mathrm{w}}=-0.902+\mathrm{i}_{\text {Solute }}+0.521 \mathrm{CP}+1.670 \mathrm{CD}+$ $0.289 \mathrm{CA}+0.757 \mathrm{CB}-1.851 \mathrm{~V} \quad \mathrm{r}^{2}=0.986$

The coefficients of the regression are similar to those of equation 8 , and negative coefficient of the volume variable is meaningful.

Table 5 gives the calculated $\log \mathrm{S}_{\mathrm{w}}$ and relative deviations (RD) from equations 5, 7, 8 and 9 as well as the GMRD value.

It can be seen that Abraham's general solvation model (equation 5) gives the highest error of average $162.0 \%$. This

\begin{tabular}{|c|c|c|c|c|c|c|c|c|c|c|c|c|}
\hline No. & Solute & $\mathrm{E}$ & $\mathrm{S}$ & A & B & $\mathrm{V}$ & $\mathrm{i}_{\text {Solute }}$ & $\mathrm{CP}$ & $\mathrm{CD}$ & $\mathrm{CB}$ & $\mathrm{CA}$ & $\log S_{W}$ \\
\hline 1 & 1,2,4,5-Tetramethylbenzene & 0.739 & 0.600 & 0.000 & 0.190 & 1.280 & 2.565 & -3.755 & -0.780 & -1.070 & 0.588 & -4.59 \\
\hline 2 & 1-Chloroanthraquinone & 1.900 & 1.790 & 0.000 & 0.507 & 1.651 & $\mathrm{NS}^{\mathrm{a}}$ & -3.128 & 1.227 & -2.578 & $\mathrm{NS}^{\mathrm{a}}$ & -5.54 \\
\hline 3 & 1-Nitronaphthalene & 1.600 & 1.590 & 0.000 & 0.290 & 1.260 & -3.918 & 4.843 & 1.747 & -3.130 & $\mathrm{NS}^{\mathrm{a}}$ & -3.54 \\
\hline 4 & 2-Chloro-5-nitrobenzoic acid & 1.250 & 1.400 & 0.670 & 0.460 & 1.228 & $\mathrm{NS}^{\mathrm{a}}$ & $\mathrm{NS}^{\mathrm{a}}$ & 0.870 & -0.604 & -0.569 & -2.59 \\
\hline 5 & 2-Methoxybenzoic acid & 0.899 & 1.410 & 0.450 & 0.620 & 1.131 & -3.808 & 5.378 & 1.780 & $\mathrm{NS}^{\mathrm{a}}$ & -1.479 & -1.55 \\
\hline 6 & 3,5-Dinitrobenzoic acid & 1.280 & 1.630 & 0.700 & 0.590 & 1.280 & -3.163 & 4.412 & 1.477 & -0.383 & -1.336 & -2.42 \\
\hline 7 & 3-Chlorobenzoic acid & 0.840 & 0.950 & 0.630 & 0.320 & 1.054 & -2.000 & 2.847 & 0.844 & $\mathrm{NS}^{\mathrm{a}}$ & -0.584 & -2.65 \\
\hline 8 & 4-Aminobenzoic acid & 1.075 & 1.650 & 0.940 & 0.600 & 1.032 & -2.796 & 3.514 & 1.331 & $\mathrm{NS}^{\mathrm{a}}$ & -1.189 & -1.37 \\
\hline 9 & 4-Chloro-3-nitrobenzoic acid & 1.250 & 1.470 & 0.700 & 0.440 & 1.228 & -4.304 & 5.856 & 1.495 & -0.813 & -1.030 & -3.00 \\
\hline 10 & 4-Methoxybenzoic acid & 0.899 & 1.250 & 0.620 & 0.520 & 1.131 & -4.465 & 5.523 & 1.452 & -0.562 & -1.148 & -2.80 \\
\hline 11 & 4-Nitrobenzoic acid & 0.990 & 1.520 & 0.680 & 0.400 & 1.106 & -3.493 & 4.323 & 1.369 & -0.867 & -1.245 & -2.98 \\
\hline 12 & 9-Fluorenone & 1.600 & 1.490 & 0.000 & 0.350 & 1.372 & -3.905 & 4.678 & 1.388 & -1.995 & $N^{a}$ & -3.98 \\
\hline 13 & Acenaphthene & 1.604 & 1.050 & 0.000 & 0.220 & 1.259 & -2.152 & 2.759 & 0.598 & -1.941 & $\mathrm{NS}^{\mathrm{a}}$ & -4.54 \\
\hline 14 & Anthracene & 2.290 & 1.340 & 0.000 & 0.280 & 1.454 & -4.225 & 3.579 & 0.651 & -2.032 & $\mathrm{NS}^{\mathrm{a}}$ & -6.43 \\
\hline 15 & Benzil & 1.445 & 1.590 & 0.000 & 0.620 & 1.637 & -5.163 & 6.076 & 1.450 & -0.675 & -0.579 & -4.05 \\
\hline 16 & Fluoranthene & 2.377 & 1.550 & 0.000 & 0.240 & 1.585 & -3.395 & 3.973 & 0.657 & -2.555 & 0.256 & -5.92 \\
\hline 17 & Fluorene & 1.588 & 1.060 & 0.000 & 0.250 & 1.357 & 1.122 & -2.715 & -1.455 & 0.519 & 0.815 & -5.00 \\
\hline 18 & Hexachlorobenzene & 1.490 & 0.990 & 0.000 & 0.000 & 1.451 & -3.785 & 3.247 & -0.266 & -1.088 & $\mathrm{NS}^{\mathrm{a}}$ & -7.68 \\
\hline 19 & Ibuprofen & 0.730 & 0.695 & 0.565 & 0.790 & 1.777 & -1.375 & $\mathrm{NS}^{\mathrm{a}}$ & 0.867 & $\mathrm{NS}^{\mathrm{a}}$ & 1.191 & -3.76 \\
\hline 20 & Naproxen & 1.510 & 2.022 & 0.600 & 0.673 & 1.782 & -4.009 & 5.901 & 1.049 & -0.780 & -1.494 & -4.16 \\
\hline 21 & Phenanthrene & 2.055 & 1.290 & 0.000 & 0.260 & 1.454 & -2.383 & 2.882 & 0.678 & -2.194 & $\mathrm{NS}^{\mathrm{a}}$ & -5.17 \\
\hline 22 & Phenothiazine & 1.890 & 1.560 & 0.310 & 0.300 & 1.479 & -4.392 & 3.366 & 1.598 & -1.817 & 0.878 & -5.10 \\
\hline 23 & Pyrene & 2.808 & 1.710 & 0.000 & 0.280 & 1.585 & -3.682 & 4.040 & 0.544 & -2.501 & 0.392 & -6.15 \\
\hline 24 & Salicylamide & 1.160 & 1.580 & 0.610 & 0.510 & 1.031 & -6.486 & 8.024 & 2.042 & $\mathrm{NS}^{\mathrm{a}}$ & -0.843 & -1.75 \\
\hline 25 & Thianthrene & 2.240 & 1.390 & 0.000 & 0.360 & 1.543 & -3.344 & 2.783 & $\mathrm{NS}^{\mathrm{a}}$ & -1.279 & 0.327 & -5.95 \\
\hline 26 & trans-Stilbene & 1.450 & 1.040 & 0.000 & 0.340 & 1.563 & -4.173 & 4.728 & 0.510 & -0.888 & -0.206 & -5.80 \\
\hline 27 & Xanthene & 1.502 & 1.070 & 0.000 & 0.230 & 1.415 & -3.053 & 3.814 & 0.335 & -1.468 & $\mathrm{NS}^{\mathrm{a}}$ & -5.21 \\
\hline
\end{tabular}

Table 4. Abraham and Catalan solute parameters and logarithm of molar aqueous solubility data for 27 chemical and pharmaceutical compounds

${ }^{a}$ NS: Not significant. 
Table 5. Relative deviations (RD) and absolute errors (AE) of calculated aqueous solubility using different equations

\begin{tabular}{|c|c|c|c|c|c|c|c|c|c|c|c|c|c|c|}
\hline \multirow[t]{3}{*}{ No } & \multirow[t]{3}{*}{ Solute } & \multirow[t]{3}{*}{$\log S_{W}$} & \multicolumn{4}{|c|}{ Calculated $\log S_{W}$} & \multicolumn{4}{|c|}{ Relative deviation (RD) } & \multicolumn{4}{|c|}{ Absolute error (AE) } \\
\hline & & & \multicolumn{4}{|c|}{ equation } & \multicolumn{4}{|c|}{ equation } & \multicolumn{4}{|c|}{ equation } \\
\hline & & & 5 & 7 & 8 & 9 & 5 & 7 & 8 & 9 & 5 & 7 & 8 & 9 \\
\hline 1 & $1,2,4,5$-Tetramethylbenzene & -4.59 & -3.76 & -4.80 & -4.93 & -4.61 & 571.9 & 38.5 & 54.6 & 3.5 & 0.83 & 0.21 & 0.34 & 0.02 \\
\hline 2 & 1-Chloroanthraquinone & -5.54 & -4.69 & -4.88 & -5.03 & -5.49 & 600.0 & 362.0 & 220.4 & 11.8 & 0.85 & 0.66 & 0.51 & 0.05 \\
\hline 3 & 1-Nitronaphthalene & -3.54 & -3.87 & -4.12 & -4.51 & -4.08 & 53.7 & 73.5 & 89.4 & 71.1 & 0.33 & 0.58 & 0.97 & 0.54 \\
\hline 4 & 2-Chloro-5-nitrobenzoic acid & -2.59 & -2.41 & -3.05 & -2.44 & -2.34 & 50.0 & 65.1 & 40.7 & 75.4 & 0.18 & 0.46 & 0.15 & 0.24 \\
\hline 5 & 2-Methoxybenzoic acid & -1.55 & -1.46 & -1.49 & -1.52 & -1.46 & 24.0 & 16.0 & 8.7 & 25.5 & 0.09 & 0.06 & 0.04 & 0.10 \\
\hline 6 & 3,5-Dinitrobenzoic acid & -2.42 & -2.16 & -2.49 & -2.20 & -2.34 & 79.2 & 15.3 & 66.0 & 18.3 & 0.26 & 0.07 & 0.22 & 0.07 \\
\hline 7 & 3-Chlorobenzoic acid & -2.65 & -2.00 & -2.98 & -2.54 & -2.13 & 344.3 & 52.9 & 27.9 & 232.2 & 0.65 & 0.33 & 0.11 & 0.52 \\
\hline 8 & 4-Aminobenzoic acid & -1.37 & -0.94 & -1.16 & -2.20 & -1.90 & 167.6 & 61.9 & 85.2 & 70.3 & 0.43 & 0.21 & 0.83 & 0.53 \\
\hline 9 & 4-Chloro-3-nitrobenzoic acid & -3.00 & -2.42 & -3.12 & -2.93 & -2.84 & 280.5 & 24.6 & 18.7 & 43.7 & 0.58 & 0.12 & 0.07 & 0.16 \\
\hline 10 & 4-Methoxybenzoic acid & -2.80 & -1.68 & -2.14 & -3.12 & -2.91 & 1233.0 & 361.4 & 52.5 & 23.1 & 1.12 & 0.66 & 0.32 & 0.11 \\
\hline 11 & 4-Nitrobenzoic acid & -2.98 & -1.87 & -2.58 & -3.16 & -2.92 & 1179.9 & 149.9 & 34.3 & 15.4 & 1.11 & 0.40 & 0.18 & 0.06 \\
\hline 12 & 9-Fluorenone & -3.98 & -4.09 & -4.38 & -4.24 & -4.10 & 21.7 & 60.3 & 45.3 & 24.2 & 0.11 & 0.40 & 0.26 & 0.12 \\
\hline 13 & Acenaphthene & -4.54 & -4.28 & -4.78 & -4.77 & -4.42 & 83.2 & 42.2 & 41.4 & 32.6 & 0.26 & 0.24 & 0.23 & 0.12 \\
\hline 14 & Anthracene & -6.43 & -5.29 & -5.61 & -6.42 & -6.40 & 1269.1 & 556.8 & 2.9 & 6.4 & 1.14 & 0.82 & 0.01 & 0.03 \\
\hline 15 & Benzil & -4.05 & -3.91 & -4.05 & -3.61 & -4.18 & 37.8 & 0.3 & 177.1 & 26.7 & 0.14 & 0.00 & 0.44 & 0.13 \\
\hline 16 & Fluoranthene & -5.92 & -5.88 & -6.39 & -5.81 & -5.92 & 10.7 & 66.4 & 30.2 & 0.2 & 0.04 & 0.47 & 0.11 & 0.00 \\
\hline 17 & Fluorene & -5.00 & -4.48 & -5.07 & -5.66 & -5.51 & 226.8 & 15.1 & 78.1 & 68.9 & 0.52 & 0.07 & 0.66 & 0.51 \\
\hline 18 & Hexachlorobenzene & -7.68 & -5.54 & -6.86 & -6.93 & -6.95 & 13609.4 & 564.2 & 466.1 & 440.1 & 2.14 & 0.82 & 0.75 & 0.73 \\
\hline 19 & Ibuprofen & -3.76 & -3.12 & -3.96 & -3.20 & -3.77 & 332.7 & 37.2 & 263.4 & 3.1 & 0.64 & 0.20 & 0.56 & 0.01 \\
\hline 20 & Naproxen & -4.16 & -3.77 & -4.35 & -3.38 & -4.40 & 146.7 & 36.0 & 503.2 & 43.1 & 0.39 & 0.19 & 0.78 & 0.24 \\
\hline 21 & Phenanthrene & -5.17 & -5.15 & -5.62 & -5.02 & -5.00 & 4.6 & 64.3 & 42.6 & 47.5 & 0.02 & 0.45 & 0.15 & 0.17 \\
\hline 22 & Phenothiazine & -5.10 & -4.57 & -5.33 & -4.82 & -4.73 & 235.8 & 41.4 & 90.1 & 135.1 & 0.53 & 0.23 & 0.28 & 0.37 \\
\hline 23 & Pyrene & -6.15 & -6.11 & -6.33 & -6.20 & -6.28 & 10.6 & 34.0 & 10.9 & 26.3 & 0.04 & 0.18 & 0.05 & 0.13 \\
\hline 24 & Salicylamide & -1.75 & -1.52 & -1.68 & -2.37 & -1.95 & 70.8 & 17.7 & 76.0 & 35.9 & 0.23 & 0.07 & 0.62 & 0.19 \\
\hline 25 & Thianthrene & -5.95 & -5.26 & -5.55 & -6.40 & -6.52 & 384.8 & 150.0 & 64.7 & 73.3 & 0.69 & 0.40 & 0.45 & 0.57 \\
\hline 26 & trans-Stilbene & -5.80 & -4.76 & -5.51 & -5.08 & -5.38 & 1009.1 & 97.1 & 430.3 & 160.6 & 1.04 & 0.29 & 0.72 & 0.42 \\
\hline \multirow[t]{3}{*}{27} & Xanthene & -5.21 & -4.66 & -5.4 & -5.19 & -5.14 & 254.0 & 36.1 & 3.6 & 18.2 & 0.55 & 0.19 & 0.02 & 0.07 \\
\hline & & & & & & Mean & 825.6 & 112.6 & 112.0 & 64.2 & 0.55 & 0.32 & 0.36 & 0.23 \\
\hline & \multicolumn{6}{|c|}{ Number of solutes with RD $>100$ (or AE $>1$ ) } & 16 & 6 & 6 & 4 & 5 & 0 & 0 & 0 \\
\hline
\end{tabular}

high error could be due to the chemicals falling outside the applicability domain of equation 5 . Therefore, to provide a nonbiased comparison, a new QSPR was drawn from Abraham descriptors (equation 7), as mentioned above. Equation 7 derived from five Abraham solute descriptors, and equation 8 which employs four solute descriptors derived from Catalan solvent scales, show similar error in correlation. By adding volume term to the equation 8 and correlating it with aqueous solubility data, equation 9 was derived. This equation shows better correlation in comparison with equations 5,7 , and 8 . The highest deviations of the calculated solubilities from the measured values are observed for hexachlorobenzene in all estimation methods, with equation 5 showing the maximum relative deviation for this compound. The number of high error solutes with relative deviations greater than $100 \%$ is 6 and 4 for equations 8 and 9 , respectively. The corresponding values for Abraham models are 16 and 6 using equations 5 and 7 , respectively.

\section{Conclusions}

In this study, we showed that Catalan and Abraham solvent parameters are rather different solvatochromic scales of solvents although similar procedures are employed for their experimental determination. The applicability of both solvent parameters in QSPR analyses was evident from the results obtained for solvents and solutes. A methodology was introduced for the calculation of new solvatochromic solute parameters based on Catalan solvent parameters. 
The method takes advantage of the coefficients of Catalan solvent parameters in multiple linear regression models of solute solubility in several nonaqueous solvents. The new solute parameters compared well with Abraham solute parameters for the estimation of aqueous solubility of compounds. The back-calculated Catalan parameters for water (coefficients of the model developed for aqueous solubility) were close to the experimental Catalan water parameters in their trend, which might confirm the suitability of the suggested method for the calculation of solute and solvent parameters.

The results of this study suggest that Catalan solvent parameters and the new solute parameters can be regarded as a valuable resource for applications in QSPR modeling. A further advantage of exploitation of Catalan parameters is the vast number of the solvents for which these parameters have already been measured which amounts to more than 150 solvents to date. For example, propylene glycol, among these solvents, is an important pharmaceutically interested solvent.

\section{Supplementary Information}

List of parameters used in this work and supplementary data are available free of charge at http://jbcs.sbq.org.br as PDF file.

\section{Acknowledgments}

The authors would like to thank the Drug Applied Research Center, Tabriz University of Medical Sciences for providing partial financial support under grant No. 88/53. We would also like to thank the reviewers for their helpful comments.

\section{References}

1. Abraham, M. H.; Kamlet, M. J.; Taft, R. W.; Doherty, R. M.; Weathersby, P. K.; J. Med. Chem. 1985, 28, 865.

2. Kamlet, M. J.; Taft, R. W.; J. Am. Chem. Soc. 1976, 98, 377.

3. Taft, R. W.; Kamlet, M. J.; J. Am. Chem. Soc. 1976, 98, 2886.

4. Kamlet, M. J.; Abboud, J. L.; Taft, R. W.; J. Am. Chem. Soc. 1977, 99, 6027.

5. Kamlet, M. J.; Abboud, J. L.; Abraham, M. H.; Taft, R. W.; J. Org. Chem. 1983, 48, 2877.

6. Abraham, M. H.; Acree Jr., W. E.; J. Phys. Org. Chem. 2008, 21,823 .

7. Catalán, J.; J. Phys. Chem. B 2009, 113, 5951.

8. Catalán, J. In Handbook of Solvents; Wypych, G., ed.; ChemTech Publishing: Toronto, Canada, 2001, ch.10.3.

9. Abraham, M. H.; Kamlet, M. J.; Taft, R. W.; J. Chem. Soc. Perkin Trans. 2 1982, 923.
10. Abraham, M. H.; Chem. Soc. Rev. 1993, 22, 73.

11. Abraham, M. H.; Acree Jr., W. E.; Cometto-Muñiz, J. E.; New J. Chem. 2009, 33, 2034.

12. Fatemi, M. H.; Abraham, M. H.; Poole, C. F.; J. Chromatogr., A 2008, 1190, 241.

13. Bowen, K. R.; Flanagan, K. B.; Acree Jr., W. E.; Abraham, M. H.; Rafols, C.; Sci. Total Environ. 2006, 371, 99.

14. Abraham, M. H.; Sánchez-Moreno, R.; Gil-Lostes, J.; Acree Jr., W. E.; Cometto-Muñiz, J. E.; Cain, W. S.; Toxicol. in Vitro 2010, 24, 357.

15. Zhao, Y. H.; Abraham, M. H.; Hersey, A.; Luscombe, C. N.; Eur. J. Med. Chem. 2003, 38, 939.

16. Jover, J.; Bosque, R.; Sales, J.; J. Chem. Inf. Model. 2004, 44, 1098.

17. Sprunger, L. M.; Proctor, A.; Acree Jr., W. E.; Abraham, M. H.; Phys. Chem. Liq. 2008, 46, 574.

18. Platts, J. A.; Butina, D.; Abraham, M. H.; Hersey, A.; J. Chem. Inf. Model. 1999, 39, 835.

19. Abraham, M. H.; Ibrahim, A.; Zissimos, A. M.; J. Chromatogr., A 2004, 1037, 29.

20. Catalán, J.; López, V.; Pérez, P.; Liebigs Ann. 1995, 5, 793.

21. Catalán, J.; Diaz, C.; López, V.; Pérez, P.; De Paz, J. L. G.; Rodríguez, J. G.; Liebigs Ann. 1996, 11, 1785.

22. Catalán, J.; Diaz, C.; Liebigs Ann. 1997, 9, 1941.

23. Catalán, J.; Hopf, H.; Eur. J. Org. Chem. 2004, 22, 4694.

24. Flanagan, K. B.; Hoover, K. R.; Acree Jr., W. E.; Abraham, M. H.; Phys. Chem. Liq. 2006, 44, 173.

25. Flanagan, K. B.; Hoover, K. R.; Garza, O.; Hizon, A.; Soto, T.; Villegas, N.; Acree Jr., W. E.; Abraham, M. H.; Phys. Chem. Liq. 2006, 44, 377.

26. Hoover, K. R.; Acree Jr., W. E.; Abraham, M. H.; J. Solution Chem. 2005, 34, 1121.

27. Stovall, D. M.; Givens, C.; Keown, S.; Hoover, K. R.; Barnes, R.; Harris, C.; Lozano, J.; Nguyen, M.; Rodriguez, E.; Acree Jr., W. E.; Abraham, M. H.; Phys. Chem. Liq. 2005, 43, 351.

28. Hoover, K. R.; Stovall, D. M.; Pustejovsky, E.; Coaxum, R.; Pop, K.; Acree Jr., W. E.; Abraham, M. H.; Can. J. Chem. 2004, $82,1353$.

29. Hoover, K. R.; Coaxum, R.; Pustejovsky, E.; Acree Jr., W. E.; Abraham, M. H.; Phys. Chem. Liq. 2004, 42, 457.

30. Hoover, K. R.; Pop, K.; Acree Jr., W. E.; Abraham, M. H.; S. Afr. J. Chem. 2005, 58, 25.

31. Daniels, C. R.; Charlton, A. K.; Wold, R. M.; Moreno, R. J.; Acree Jr., W. E.; Abraham, M. H.; Phys. Chem. Liq. 2004, 42, 633.

32. Hoover, K. R.; Coaxum, R.; Pustejovsky, E.; Stovall, D. M.; Acree Jr., W. E.; Abraham, M. H.; Phys. Chem. Liq. 2004, 42, 339.

33. Stovall, D. M.; Acree Jr., W. E.; Abraham, M. H.; Fluid Phase Equilib. 2005, 232, 113.

34. Acree Jr., W. E.; Abraham, M. H.; Fluid Phase Equilib. 2002, 201, 245. 
35. Acree Jr., W. E.; Abraham, M. H.; Can. J. Chem. 2001, 79, 1466.

36. Acree Jr., W. E.; Abraham, M. H.; J. Solution Chem. 2002, 31, 293.

37. Monárrez, C. I.; Acree Jr., W. E.; Abraham, M. H.; Phys. Chem. Liq. 2002, 40, 581.

38. Stovall, D. M.; Givens, C.; Keown, S.; Hoover, K. R.; Rodriguez, E.; Acree Jr., W. E.; Abraham, M. H.; Phys. Chem. Liq. 2005, 43, 261.

39. Daniels, C. R.; Charlton, A. K.; Wold, R. M.; Pustejovsky, E.; Furman, A. N.; Bilbrey, A. C.; Love, J. N.; Garza, J. A.; Acree Jr., W. E.; Abraham, M. H.; Phys. Chem. Liq. 2004, 42, 481.

40. Hoover, K. R.; Acree Jr., W. E.; Abraham, M. H.; Phys. Chem. Liq. 2006, 44, 367.
41. Blake-Taylor, B. H.; Deleon, V. H.; Acree Jr., W. E.; Abraham, M. H.; Phys. Chem. Liq. 2007, 45, 389.

42. Abraham, M. H.; Green, C. E.; Acree Jr., W. E.; Hernandez, C. E.; Roy, L. E.; J. Chem. Soc. Perkin Trans. 2 1998, 2677.

43. Smallwood, I. M.; Handbook of Organic Solvents Properties, Arnold Hodder Headline Group: London, 1996.

44. Jouyban, A.; Handbook of Solubility Data for Pharmaceuticals, CRC Press, Taylor \& Francis Group: Boca Raton, 2009.

45. Abraham, M. H.; Acree Jr., W. E.; Leo, A. J.; Hoekman, D.; New J. Chem. 2009, 33, 568.

46. Ghafourian, T., Bozorgi, A. H. A. Eur. J. Pharm. Sci. 2010, 40, 430. 


\title{
QSPR Modeling Using Catalan Solvent and Solute Parameters
}

\author{
Abolghasem Jouyban, ${ }^{* a}$ Mohammad A. A. Fakhree, ${ }^{b}$ Ali Shayanfar ${ }^{c}$ and \\ Taravat Ghafourian ${ }^{d}$
}

${ }^{a}$ Drug Applied Research Center, Department of Pharmaceutical and Food Control,
Faculty of Pharmacy, Tabriz University of Medical Sciences, Tabriz 51664, Iran

${ }^{b}$ Kimia Research Institute, Tabriz, Iran

${ }^{c}$ Liver and Gastrointestinal Diseases Research Center, Tabriz University of Medical Sciences, Tabriz, Iran

${ }^{d}$ Medway School of Pharmacy, Universities of Kent and Greenwich, Kent ME4 4TB, United Kingdom

Table S1. List of parameters used in this study

\begin{tabular}{|c|c|c|c|}
\hline Parameter & Definition & Parameter & Definition \\
\hline A & Abraham' hydrogen bonding acidity parameter for the solute & SPP & Catalan polarity/polarizability parameter for the solvent \\
\hline B & Abraham' hydrogen bonding basicity parameter for the solute & $\mathrm{SP}(\mathrm{cp})$ & Catalan polarizability parameter for the solvent \\
\hline S & Abraham' polarity/polarizability parameter for the solute & $\mathrm{SdP}(\mathrm{cd})$ & Catalan dipolarity parameter for the solvent \\
\hline $\mathrm{E}$ & Excess molar refraction of the solute & $\mathrm{SB}(\mathrm{cb})$ & Catalan basicity parameter for the solvent \\
\hline V & One percent of McGowan volume of the solute & SA (ca) & Catalan acidity parameter for the solvent \\
\hline $\mathrm{c}$ & Abraham' constant value for the solvent & $\mathrm{i}_{\text {Solute }}$ & Catalan constant value for the solute* \\
\hline $\mathrm{a}$ & $\begin{array}{l}\text { Abraham' interaction term of the solvent with acidity of the solute } \\
\text { (solvent basicity) }\end{array}$ & $\mathrm{CP}$ & Catalan polarizability parameter for the solute ${ }^{*}$ \\
\hline $\mathrm{b}$ & $\begin{array}{l}\text { Abraham' interaction term of the solvent with basicity of the solute } \\
\text { (solvent acidity) }\end{array}$ & $\mathrm{CD}$ & Catalan dipolarity parameter for the solute ${ }^{*}$ \\
\hline $\mathrm{s}$ & $\begin{array}{l}\text { Abraham' interaction term of the solvent with polarity/polarizability } \\
\text { of the solute }\end{array}$ & $\mathrm{CB}$ & Catalan basicity parameter for the solute ${ }^{*}$ \\
\hline e & $\begin{array}{l}\text { Abraham' interaction term of the solvent with molar refraction of } \\
\text { the solute }\end{array}$ & CA & Catalan acidity parameter for the solute ${ }^{*}$ \\
\hline $\mathrm{v}$ & $\begin{array}{l}\text { Abraham' interaction term of the solvent with molar volume of } \\
\text { the solute }\end{array}$ & $\mathrm{i}_{\mathrm{W}}$ & Intercept of the aqueous solubility prediction equation* \\
\hline
\end{tabular}

*These parameters were resulted from this study. 
Table S2. Abraham solvent parameters (c, e, s, a, b, and v) for available solvents and their related Catalan solvent parameters (cp, cd, cb, and ca)

\begin{tabular}{|c|c|c|c|c|c|c|c|c|c|c|c|}
\hline No. & Solvent & $\mathrm{c}$ & e & $\mathrm{s}$ & $\mathrm{a}$ & $\mathrm{b}$ & $\mathrm{v}$ & $\mathrm{cp}$ & $\mathrm{cd}$ & $\mathrm{ca}$ & $\mathrm{cb}$ \\
\hline 1 & 1,2-Dichloroethane & 0.227 & 0.278 & -0.167 & -2.816 & -4.324 & 4.205 & 0.771 & 0.742 & 0.030 & 0.126 \\
\hline 2 & 1,4-Dioxane & 0.098 & 0.350 & -0.083 & -0.556 & -4.826 & 4.172 & 0.737 & 0.312 & 0.000 & 0.444 \\
\hline 3 & Butan-1-ol & 0.152 & 0.437 & -1.175 & 0.098 & -3.914 & 4.119 & 0.674 & 0.655 & 0.341 & 0.809 \\
\hline 4 & Decan-1-ol & -0.062 & 0.754 & -1.461 & 0.063 & -4.053 & 4.293 & 0.722 & 0.383 & 0.259 & 0.912 \\
\hline 5 & Heptan-1-ol & -0.026 & 0.491 & -1.258 & 0.035 & -4.155 & 4.415 & 0.706 & 0.499 & 0.302 & 0.912 \\
\hline 6 & Hexan-1-ol & 0.044 & 0.470 & -1.153 & 0.083 & -4.057 & 4.249 & 0.698 & 0.552 & 0.315 & 0.879 \\
\hline 7 & Octan-1-ol & -0.034 & 0.490 & -1.048 & -0.028 & -4.229 & 4.219 & 0.713 & 0.454 & 0.299 & 0.923 \\
\hline 8 & Pentan-1-ol & 0.080 & 0.521 & -1.294 & 0.208 & -3.908 & 4.208 & 0.687 & 0.587 & 0.319 & 0.860 \\
\hline 9 & Propan-1-ol & 0.148 & 0.436 & -1.098 & 0.389 & -3.893 & 4.036 & 0.658 & 0.748 & 0.367 & 0.782 \\
\hline 10 & Butan-2-ol & 0.106 & 0.272 & -0.988 & 0.196 & -3.805 & 4.110 & 0.656 & 0.706 & 0.221 & 0.888 \\
\hline 11 & 2-Methyl propan-1-ol & 0.177 & 0.335 & -1.099 & 0.069 & -3.570 & 3.990 & 0.657 & 0.684 & 0.311 & 0.828 \\
\hline 12 & 2-Methyl propan-2-ol & 0.197 & 0.136 & -0.916 & 0.318 & -4.031 & 4.113 & 0.632 & 0.732 & 0.145 & 0.928 \\
\hline 13 & Propan-2-ol & 0.063 & 0.320 & -1.024 & 0.445 & -3.824 & 4.067 & 0.633 & 0.808 & 0.283 & 0.830 \\
\hline 14 & Propan-2-one & 0.335 & 0.349 & -0.231 & -0.411 & -4.793 & 3.963 & 0.651 & 0.907 & 0.000 & 0.475 \\
\hline 15 & Acetonitrile & 0.413 & 0.077 & 0.326 & -1.566 & -4.391 & 3.364 & 0.645 & 0.974 & 0.044 & 0.286 \\
\hline 16 & Benzene & 0.142 & 0.464 & -0.588 & -3.099 & -4.625 & 4.491 & 0.793 & 0.270 & 0.000 & 0.124 \\
\hline 17 & Carbon disulfide & 0.047 & 0.686 & -0.943 & -3.603 & -5.818 & 4.921 & 1.000 & 0.000 & 0.000 & 0.104 \\
\hline 18 & Carbone tetrachloride & 0.260 & 0.573 & -1.254 & -3.558 & -4.558 & 4.589 & 0.768 & 0.000 & 0.000 & 0.044 \\
\hline 19 & Chlorobenzene & 0.040 & 0.246 & -0.462 & -3.038 & -4.769 & 4.640 & 0.833 & 0.537 & 0.000 & 0.182 \\
\hline 20 & Chloroform & 0.327 & 0.157 & -0.391 & -3.191 & -3.437 & 4.191 & 0.783 & 0.614 & 0.047 & 0.071 \\
\hline 21 & Cyclohexane & 0.159 & 0.784 & -1.678 & -3.740 & -4.929 & 4.577 & 0.683 & 0.000 & 0.000 & 0.073 \\
\hline 22 & Dibutyl ether & 0.203 & 0.369 & -0.954 & -1.488 & -5.426 & 4.508 & 0.672 & 0.175 & 0.000 & 0.637 \\
\hline 23 & Dichloromethane & 0.314 & 0.001 & 0.022 & -3.238 & -4.137 & 4.259 & 0.761 & 0.769 & 0.040 & 0.178 \\
\hline 24 & Diethyl ether & 0.308 & 0.377 & -0.813 & -0.468 & -5.012 & 4.379 & 0.617 & 0.385 & 0.000 & 0.562 \\
\hline 25 & Dimethylformamide & -0.438 & -0.099 & 0.670 & 0.878 & -4.970 & 4.552 & 0.759 & 0.977 & 0.031 & 0.613 \\
\hline 26 & Dodecane & 0.114 & 0.668 & -1.644 & -3.545 & -5.006 & 4.459 & 0.683 & 0.000 & 0.000 & 0.086 \\
\hline 27 & Ethanol & 0.208 & 0.409 & -0.959 & 0.186 & -3.645 & 3.928 & 0.633 & 0.783 & 0.400 & 0.658 \\
\hline 28 & Ethyl acetate & 0.358 & 0.362 & -0.449 & -0.668 & -5.016 & 4.155 & 0.656 & 0.603 & 0.000 & 0.542 \\
\hline 29 & Ethylene glycol & 0.243 & 0.695 & -0.670 & 0.726 & -2.399 & 2.670 & 0.777 & 0.910 & 0.717 & 0.534 \\
\hline 30 & Heptane & 0.325 & 0.670 & -2.061 & -3.317 & -4.733 & 4.543 & 0.635 & 0.000 & 0.000 & 0.083 \\
\hline 31 & Hexadecane & 0.087 & 0.667 & -1.617 & -3.587 & -4.869 & 4.433 & 0.704 & 0.000 & 0.000 & 0.086 \\
\hline 32 & Hexane & 0.361 & 0.579 & -1.723 & -3.599 & -4.764 & 4.344 & 0.616 & 0.000 & 0.000 & 0.056 \\
\hline 33 & Isooctane & 0.288 & 0.382 & -1.668 & -3.639 & -5.000 & 4.461 & 0.618 & 0.000 & 0.000 & 0.044 \\
\hline 34 & Methanol & 0.329 & 0.299 & -0.671 & 0.080 & -3.389 & 3.512 & 0.608 & 0.904 & 0.605 & 0.545 \\
\hline 35 & Methylcyclohexane & 0.246 & 0.782 & -1.982 & -3.517 & -4.293 & 4.528 & 0.675 & 0.000 & 0.000 & 0.069 \\
\hline 36 & Methy-tert-butyl ether & 0.376 & 0.264 & -0.788 & -1.078 & -5.030 & 4.410 & 0.622 & 0.422 & 0.000 & 0.567 \\
\hline 37 & Nonane & 0.240 & 0.619 & -1.713 & -3.532 & -4.921 & 4.482 & 0.660 & 0.000 & 0.000 & 0.053 \\
\hline 38 & Octane & 0.223 & 0.642 & -1.647 & -3.480 & -5.067 & 4.526 & 0.650 & 0.000 & 0.000 & 0.079 \\
\hline 39 & Tetrahydrofuran & 0.207 & 0.372 & -0.392 & -0.236 & -4.934 & 4.447 & 0.714 & 0.634 & 0.000 & 0.591 \\
\hline 40 & Toluene & 0.143 & 0.527 & -0.720 & -3.010 & -4.824 & 4.545 & 0.782 & 0.284 & 0.000 & 0.128 \\
\hline 41 & Undecane & 0.058 & 0.603 & -1.661 & -3.421 & -5.120 & 4.619 & 0.678 & 0.000 & 0.000 & 0.080 \\
\hline
\end{tabular}


Table S3. Melting point (mp), boiling point (bp), flash point (fp), refractive index ( $n$ ), surface tension $(\gamma)$, viscosity $(\eta)$, density $(\rho)$, and solubility parameter (SP) data of 54 common solvents ${ }^{a}$

\begin{tabular}{|c|c|c|c|c|c|c|c|c|c|}
\hline No. & Solvent & $\mathrm{mp}(\mathrm{K})$ & bp $(\mathrm{K})$ & $\mathrm{fp}(\mathrm{K})$ & $n$ & $\gamma\left(\right.$ dyn $\left.\mathrm{cm}^{-1}\right)$ & $\eta(\mathrm{cP})$ & $\rho\left(\mathrm{g} \mathrm{cm}^{-3}\right)$ & SP \\
\hline 1 & 1,1,1-Tricloroethane & 243 & 347 & & 1.438 & 30 & 0.65 & 1.338 & 7.7 \\
\hline 2 & 1,2-Dichloroethane & 237 & 356.5 & 286 & 1.444 & 32.2 & 0.9 & 1.253 & 9.8 \\
\hline 3 & 1,2-Propanediol & 213 & 460 & 372 & 1.431 & 72 & 54 & 1.0362 & \\
\hline 4 & 1,4-Dioxane & 285 & 374 & 285 & 1.42 & 40 & 1.3 & 1.034 & 10 \\
\hline 5 & 2,2,4-Trimethyl pentane & 166 & 372 & 261 & 1.389 & 18.33 & 0.477 & 0.692 & 7.4 \\
\hline 6 & Acetic Acid & 290 & 391 & 313 & 1.37 & 27.4 & 1.13 & 1.051 & 10.1 \\
\hline 7 & Acetone & 178 & 329 & 255 & 1.357 & 23.3 & 0.33 & 0.79 & 10 \\
\hline 8 & Acetonitrile & 229 & 354.6 & 279 & 1.342 & 29.1 & 0.38 & 0.782 & 11.9 \\
\hline 9 & Acetophenone & 292.6 & 475 & 355 & 1.532 & 12 & 1.74 & 1.024 & \\
\hline 10 & Aniline & 267 & 457 & 349 & 1.583 & 45.5 & 4.4 & 1.022 & 10.3 \\
\hline 11 & Benzene & 278.5 & 353 & 262 & 1.498 & 28.9 & 0.65 & 0.879 & 9.2 \\
\hline 12 & Carbon disulphide & 162 & 319 & 243 & 1.628 & 32 & 0.36 & 1.26 & 10 \\
\hline 13 & Carbon tetrachloride & 250 & 349 & & 1.459 & 27 & 0.97 & 1.58 & 8.6 \\
\hline 14 & Chloroform & 250 & 334 & & 1.444 & 27.16 & 0.57 & 1.48 & 9.3 \\
\hline 15 & Cyclohexane & 279.5 & 354 & 256 & 1.424 & 24.98 & 0.98 & 0.778 & 8.2 \\
\hline 16 & Cyclohexanone & 241 & 429 & 316 & 1.448 & 34.5 & 2.2 & 0.948 & 9.9 \\
\hline 17 & Dibutyl ether & 178 & 415 & 298 & 1.397 & $22.4^{\mathrm{a}}$ & 0.63 & 0.769 & 7.2 \\
\hline 18 & Diethyl ether & 157 & 307.5 & 228 & 1.352 & 17 & 0.24 & 0.715 & 7.4 \\
\hline 19 & Diisopropyl ether & 187 & 341 & 245 & 1.367 & 18 & 0.33 & 0.724 & 6.9 \\
\hline 20 & Dimethylacetamide & 253 & 439 & 343 & 1.436 & 34 & 0.92 & 0.945 & 11 \\
\hline 21 & Dimethylformamide & 212 & 426 & 335 & 1.427 & 35 & 0.82 & 0.945 & 12.1 \\
\hline 22 & Dimethylsulphoxide & 291.5 & 462 & 368 & 1.476 & 43.7 & 2 & 1.101 & 13 \\
\hline 23 & Ethanediol & 260 & 471 & 384 & 1.429 & 46.5 & 20 & 1.115 & 14.6 \\
\hline 24 & Ethanol & 159 & 351 & 286 & 1.359 & 22.3 & 1.08 & 0.789 & 13.4 \\
\hline 25 & Ethyl acetate & 189 & 350 & 269 & 1.37 & 24 & 0.46 & 0.895 & 9.1 \\
\hline 26 & Ethylbenzene & 179 & 409 & 288 & 1.493 & 29.2 & 0.72 & 0.867 & 8.9 \\
\hline 27 & $i$-Butanol & 165 & 381 & 298 & 1.394 & 22.8 & 3.96 & 0.802 & 10.7 \\
\hline 28 & $i$-Propanol & 185 & 355 & 285 & 1.375 & 21.7 & 2 & 0.786 & 11.5 \\
\hline 29 & Methanol & 175 & 337 & 288 & 1.326 & 22.6 & 0.6 & 0.792 & 14.5 \\
\hline 30 & Methyl acetate & 175 & 330 & 263 & 1.36 & 24 & 0.37 & 0.927 & 9.6 \\
\hline 31 & Methyl ethyl ketone & 186 & 353 & 267 & 1.377 & 24.6 & 0.41 & 0.805 & 9.3 \\
\hline 32 & Methy-tert-butyl ether & 164 & 328 & 239 & 1.369 & 18.3 & 0.35 & 0.741 & 7.4 \\
\hline 33 & Methylene chloride & 178 & 313 & & 1.4211 & 28.1 & 0.44 & 1.326 & 9.7 \\
\hline 34 & Monochlorobenzene & 227 & 405 & 302 & 1.523 & 33 & 0.8 & 1.106 & 9.5 \\
\hline 35 & $n$-Amyl alcohol & 195 & 411 & 321 & 1.408 & 25.6 & 4 & 0.815 & \\
\hline 36 & $n$-Butanol & 193 & 391 & 308 & 1.397 & 24.6 & 3 & 0.81 & 11.4 \\
\hline 37 & $n$-Butyl acetate & 200 & 399 & 295 & 1.392 & 25.1 & 0.73 & 0.876 & 8.6 \\
\hline 38 & $n$-Decane & 243 & 447 & 317 & 1.408 & & & 0.73 & 6.7 \\
\hline 39 & $n$-Heptane & 182 & 371 & 269 & 1.385 & 19.3 & 0.41 & 0.664 & 7.5 \\
\hline 40 & $n$-Hexane & 178 & 342 & 251 & 1.372 & 18.4 & 0.31 & 0.659 & 6.9 \\
\hline 41 & Nitrobenzene & 279 & 484 & 361 & 1.55 & 43.9 & 1.8 & 1.204 & 10 \\
\hline 42 & $n$-Methyl-2-pyrrolidone & 249 & 475 & 368 & 1.468 & 40.7 & 1.8 & 1.03 & 11 \\
\hline 43 & $n$-Nonane & 220 & 424 & 304 & 1.403 & 22.9 & 0.67 & 0.718 & \\
\hline 44 & $n$-Octane & 216 & 399 & 286.3 & 1.395 & 21.7 & 0.5 & 0.703 & \\
\hline 45 & $n$-Octanol & 257 & 467 & 354 & 1.427 & 27.5 & 7.5 & 0.827 & 10.4 \\
\hline 46 & $n$-Pentane & 144 & 309 & 233 & 1.358 & 16 & 0.235 & 0.626 & 7 \\
\hline 47 & $n$-Propanol & 146 & 370 & 298 & 1.383 & 23.7 & 1.72 & 0.804 & 11.9 \\
\hline 48 & Pyridine & 231 & 388 & 293 & 1.507 & 36.6 & 0.88 & 0.983 & 10.7 \\
\hline 49 & 2-Butanol & 158 & 372.5 & 294 & 1.395 & 23 & 3.7 & 0.807 & 10.8 \\
\hline 50 & Sulfolane & 300.4 & 558 & 450 & 1.471 & 35.5 & 10.3 & 1.26 & \\
\hline 51 & Tetrahydrofuran & 164 & 339 & 258 & 1.404 & 28 & 0.55 & 0.888 & 9.1 \\
\hline 52 & Toluene & 178 & 383.6 & 277 & 1.494 & 28.5 & 0.59 & 0.867 & 8.9 \\
\hline 53 & Water & 273 & 373 & & 1.332 & 72.75 & 0.89 & 0.998 & 23.4 \\
\hline 54 & Xylenes (mixed isomers) & & 409 & 296 & 1.496 & 28.6 & 0.7 & 0.87 & 8.9 \\
\hline
\end{tabular}

\footnotetext{
${ }^{a}$ http://www.springerlink.com/content/r364t1631p53p436/, accessed in September 2009.
} 